Mechani sm of $\mathrm{pH}$ var $\mathrm{i}$ at $\mathrm{i}$ on and $\mathrm{H} 2 \mathrm{O} 2$ gener at $\mathrm{i}$ on i n water exposed to pul sed di scharge pl asna

\begin{tabular}{|l|l|}
\hline 著者 & $\begin{array}{l}\text { WAK SAKA Shogo, TSUDA Koshi, TAKAHASH } \\
\text { Kazuhi ro, SATOH Kohki }\end{array}$ \\
\hline $\begin{array}{l}\text { j our nal or } \\
\text { publ i cat } \mathrm{i} \text { on } \mathrm{t} \text { i t l e }\end{array}$ & I EEE Tr ansact i ons on PI asma Sci ence \\
\hline vol une & 47 \\
\hline number & 2 \\
\hline page r ange & 1083 1088 \\
\hline year & 2018 09-03 \\
\hline URL & ht t p: //hdl . handl e. net /10258/00009936 \\
\hline
\end{tabular}




\title{
Mechanism of $\mathrm{pH}$ variation and $\mathrm{H}_{2} \mathrm{O}_{2}$ generation in water exposed to pulsed discharge plasma
}

\author{
Shogo Wakisaka, Kohshi Tsuda, Kazuhiro Takahashi, and Kohki Satoh
}

\begin{abstract}
Positive and negative pulsed discharge plasma is generated above test liquid containing $\mathrm{NaCl}$ in $\mathrm{Ar}$ atmosphere, and the spatiotemporal variation of $\mathbf{p H}$ value in the liquid is visualized by a colorimetric method using bromothymol blue. Furthermore, polarity effects on $\mathrm{H}_{2} \mathrm{O}_{2}$ generation are examined by electrochemical calculation and a colorimetric method using titanium sulfate. When the positive pulsed discharge plasma is generated, the $\mathrm{pH}$ value of the liquid is decreased by $\mathrm{H}^{+}$generation through the dissociation of $\mathrm{H}_{2} \mathrm{O}^{+}$, formed by the charge exchange reaction between $\mathrm{Ar}^{+}$and $\mathrm{H}_{2} \mathrm{O}$, while the $\mathrm{pH}$ value of the vicinity of an earthed electrode is increased by $\mathrm{OH}^{-}$generation through the electrolysis of water. When the negative pulsed discharge plasma is generated, the $\mathrm{pH}$ value of the liquid is increased by $\mathrm{OH}^{-}$generation and $\mathrm{H}^{+}$reduction respectively through the reaction of hydrated electrons with $\mathrm{H}_{2} \mathrm{O}$ and $\mathrm{H}^{+}$, while the $\mathrm{pH}$ value in the vicinity of the earthed electrode is decreased by $\mathrm{H}^{+}$generation through the electrolysis of water. The generation of $\mathrm{H}_{2} \mathrm{O}_{2}$ is found to be promoted when the positive pulsed discharge plasma is generated, and this increase rate of $\mathrm{H}_{2} \mathrm{O}_{2}$ is in approximate agreement with calculated generation rate of $\mathrm{H}_{2} \mathrm{O}_{2}$, which is produced from $\mathrm{OH}$ generated by electrolysis.
\end{abstract}

Index Terms-Plasma applications, Colorimetric method, Pulsed discharge plasma, $\mathrm{pH}$ measurement.

\section{INTRODUCTION}

$\mathrm{N}$ ON-THERMAL atmospheric pressure plasma in contact with water has been widely studied for realizing a variety of plasma applications such as agriculture [1], [2], sterilization [3], [4], medicine [5], [6], food processing [7], nanoparticle fabrication [8], etc. In general, many kinds of reactive oxygen species (ROS), such as $\mathrm{H}_{2} \mathrm{O}_{2}, \mathrm{OH}$, and $\mathrm{HO}_{2}$ radicals, are produced in water by discharge plasma exposure, and these species have high oxidation potential; therefore, the water containing ROS contributes to disinfecting microorganisms [9] and decomposing organic dye [10], [11]. Furthermore, many kinds of reactive nitrogen species (RNS), such as $\mathrm{NO}_{2}^{-}$, $\mathrm{NO}_{3}{ }^{-}$, and $\mathrm{ONOOH}$, are produced in the water when the discharge plasma is generated in air. RNS have the effects of improving a plant growth rate [1], [12] and maintaining the flavor of food [7]. Since the efficiency of those applications is strongly affected by the kinds and the concentrations of ROS/RNS, these must be properly controlled.

In recent years, Ikawa et al. [13] and Lukes et al. [14] reported the bactericidal effects of water containing ROS/RNS and the production process of ROS/RNS by plasma exposure. Ikawa et al. exposed a low-frequency plasma jet to an aqueous solution containing Escherichia coli, and reported that the time to achieve one order reduction of $E$. coli colony number is reduced to one-tenth by decreasing the $\mathrm{pH}$ value of the solution from 5.2 to 3.7. It is also reported that the bactericidal effects may be caused by $\mathrm{HO}_{2}$ radical in the solutions. Lukes et al. reported that an acidic aqueous solution enhances bactericidal

(Corresponding authors: S. Wakisaka; K. Takahashi.)

S. Wakisaka, K. Tsuda, K. Takahashi, and K. satoh are with Muroran Institute of Technology, Muroran 050-8585, Japan (e-mail: effects by $\mathrm{ONOOH}$ produced through the reaction of $\mathrm{H}_{2} \mathrm{O}_{2}$ with $\mathrm{NO}_{2}{ }^{-}$. Therefore, it is important to control $\mathrm{pH}$ value of water for improving bactericidal effects. Several groups reported the variation of $\mathrm{pH}$ value induced by plasma exposure to water. Shimizu et al. [15] generated discharge plasma above a methyl red aqueous solution in air, and reported that the decrease of $\mathrm{pH}$ value in the solution is caused by the production of $\mathrm{H}^{+}$through the dissolution of $\mathrm{NO}_{\mathrm{x}}$. Further, Tian and Kushner [16] computationally predicted that $\mathrm{H}^{+}$can be produced in water through the charge exchange reaction between positive ions, generated in plasma, and water molecules; however, the variation of $\mathrm{pH}$ value caused by the charge exchange reaction has not been demonstrated experimentally as far as we know.

In this work, pulsed discharge plasma with positive and negative polarities was generated above aqueous solutions in $\mathrm{Ar}$ atmosphere, and the spatiotemporal variations of $\mathrm{pH}$ value in the solutions were observed by a colorimetric method. Then, the process of the $\mathrm{pH}$ variation in the solutions was discussed on the basis of the observations. Furthermore, polarity effects on the concentration of $\mathrm{H}_{2} \mathrm{O}_{2}$ were examined using a colorimetric method and electrochemical calculation.

\section{EXPERIMENTAL SETUP AND PROCEDURE}

Figure 1 shows a schematic diagram of the experimental apparatus. A discharge chamber to generate the pulsed

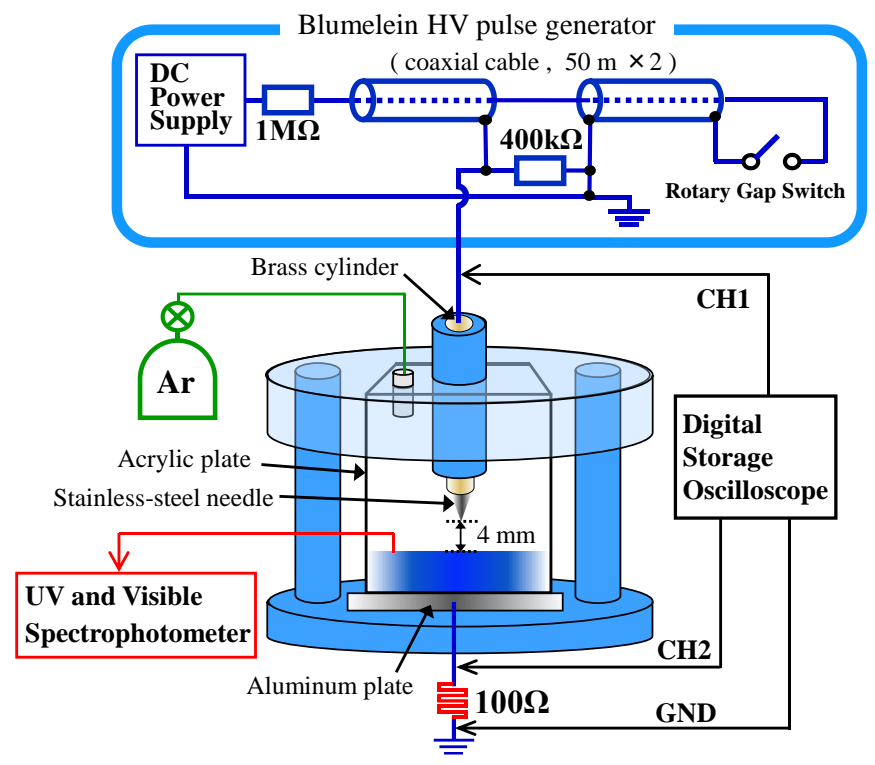

Fig. 1. Schematic diagram of experimental apparatus.

16043070@mmm.muroran-it.ac.jp; 14024116@mmm.muroran-it.ac.jp; ktakahashi@mmm.muroran-it.ac.jp; ksatoh@mmm.muroran-it.ac.jp;) 
discharge plasma consisted of a needle electrode and a liquid container. The needle electrode was made of stainless steel and had $4.0 \mathrm{~mm}$ in diameter and $30 \mathrm{~mm}$ in length. The liquid container consisted of a bottom planar electrode and four sidewalls. The bottom electrode was an aluminum square plate of $85 \mathrm{~mm}$ in width, which is earthed, and the sidewalls were made of acrylic resin with $85 \mathrm{~mm}$ in width and $90 \mathrm{~mm}$ in height. Test liquid was $200 \mathrm{~mL}$ of $\mathrm{NaCl}$ aqueous solution. The test liquid was poured into the liquid container, and the distance between the tip of the needle electrode and the liquid surface was fixed at $4 \mathrm{~mm}$. To remove dissolved air in the liquid and prevent $\mathrm{pH}$ decrease due to the generation of nitrogen oxide from the air by plasma exposure, Ar gas, the purity of which is $99.99 \%$, was sparged into the test liquid from a gas tube immersed in the test liquid, which is not illustrated in Fig. 1. After the sparging, Ar gas was fed into the liquid container at a constant flow rate of $1 \mathrm{~L} / \mathrm{min}$ as an atmospheric gas, as shown in Fig. 1. A pulsed high voltage with a pulse width of $500 \mathrm{~ns}$ generated by a Blumelein pulse generator, which has two coaxial transmission lines (Fujikura 8D-2V) with a length of 50 $\mathrm{m}$ and capacitance of $5 \mathrm{nF}$, was applied to the needle electrode to generate the pulsed discharge above the test liquid. The coaxial transmission lines were charged to a negative and positive voltage of $14.14 \mathrm{kV}$, and the pulse repetition rate was 20 pulses per second, which corresponds to a duty cycle of $1.0 \times 10^{-5}$. The applied voltage was measured using a fourchannel digital storage oscilloscope (Iwatsu DS-5524A) through a high-voltage probe (Iwatsu Test Instruments HVP30). A discharge current was obtained by measuring the voltage drop across a non-inductive resistor connected in series between the bottom electrode and the earth, and the voltage drop was measured using the digital storage oscilloscope. The input power was calculated by multiplying the voltage across the gap and the discharge current, and the input energy was obtained from the time integration of the input power. The variation of $\mathrm{pH}$ value was visualized by bromothymol blue (BTB). BTB assumes greenish blue in a neutral aqueous solution, and the color changes to yellow bellow $\mathrm{pH} 6.0$ and blue above $\mathrm{pH}$ 7.6. Titanium sulfate was used to visualize and determine $\mathrm{H}_{2} \mathrm{O}_{2}$ concentration. Titanium sulfate is in the form of titanium and sulfate ions in water, and titanium ions react with $\mathrm{H}_{2} \mathrm{O}_{2}$ to form peroxotitanium complex [17], which has peak absorption at $510 \mathrm{~nm}$ and assumes yellow. BTB of 3.84 $\mu \mathrm{mol}$ and $0.624 \mathrm{mmol}$ of titanium sulfate were added to the test liquid to show color changes due to the variation of $\mathrm{pH}$ value and $\mathrm{H}_{2} \mathrm{O}_{2}$ production, respectively. The conductivity of the test liquid with BTB and titanium sulfate was set to $17 \mathrm{mS} / \mathrm{cm}$ by varying $\mathrm{NaCl}$ concentration. Titanium sulfate dissolved in the test liquid may be decomposed by the pulsed discharge plasma exposure, and this interferes with the accurate measurement of $\mathrm{H}_{2} \mathrm{O}_{2}$ concentration. Therefore, only the test liquid, the conductivity of which is $17 \mathrm{mS} / \mathrm{cm}$, was exposed to the pulsed discharge plasma, and then titanium sulfate was added to the test liquid to measure $\mathrm{H}_{2} \mathrm{O}_{2}$ concentration. The absorbance of the test liquid was measured using UV/Vis spectrophotometer (SHIMADZU UV-1800), and the $\mathrm{H}_{2} \mathrm{O}_{2}$ concentration was deduced according to the Lambert-Beer's law. The color changes of the test liquid containing BTB and titanium sulfate were recorded from the front side of the liquid container using

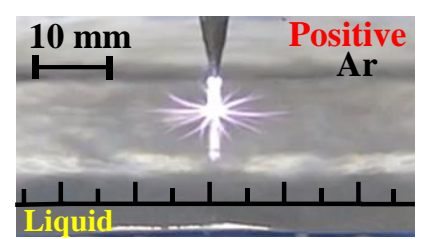

(a) Positive polarity

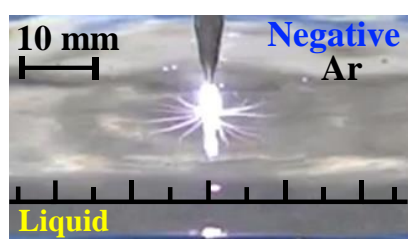

(b) Negative polarity
Fig. 2. Photographs of single pulsed discharge propagation.

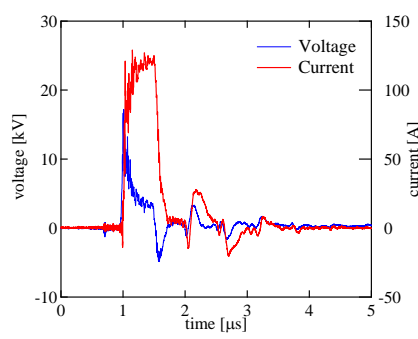

(a) Positive polarity

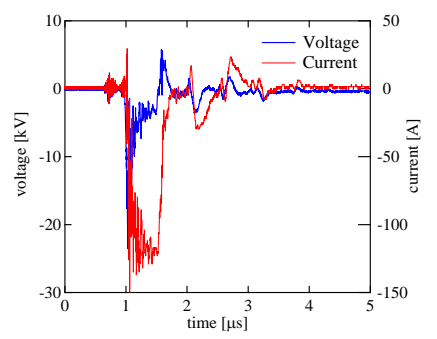

(b) Negative polarity
Fig. 3. Waveforms of discharge voltage and discharge current.

a digital camera (Canon EOS-Kiss X7) with an exposure time of $1 / 60 \mathrm{~s}$ and a flame rate of $30 \mathrm{fps}$.

\section{CHARACTERISTICS OF PULSED DISCHARGE PLASMA}

Figure 2 shows the representative photographs of a single pulsed discharge above the test liquid when the positive and negative pulsed voltages are applied, taken by the digital camera with an exposure time of $50 \mathrm{~ms}$. The discharge plasma reaches the liquid surface, and then radially spreads approximately $10 \mathrm{~mm}$ over the liquid in both the polarities. No significant difference is observed in the branch length and the diameter of the discharges between the positive and negative pulsed discharge plasma. Figure 3 shows the typical waveforms of the discharge voltage and current when the positive and negative pulsed discharge plasma is generated. Input energies of the positive and negative pulsed discharge are 0.253 and $0.238 \mathrm{~J} /$ pulse, respectively. Therefore, the electrical characteristics of the positive and negative pulsed discharge are regarded as almost the same.

\section{VISUALIZATION OF PH IN TEST LIQUID}

Figure 4 shows the color change in the test liquid containing BTB by the pulsed discharge plasma exposure. When the positive pulsed discharge plasma is generated, the color of the liquid below the discharge area turns yellow, and the colored area propagates downward at $2 \mathrm{~s}$. The coloration indicates the decrease of $\mathrm{pH}$ value, namely, the generation of $\mathrm{H}^{+}$. Tien and Kushner [16] predicted that $\mathrm{H}_{2} \mathrm{O}^{+}$is produced by the charge exchange between positive ions in plasma and water molecules, and that $\mathrm{H}_{2} \mathrm{O}^{+}$is dissociated into $\mathrm{H}^{+}$and $\mathrm{OH}$ in water. In the pulsed plasma generated here, argon atoms can be ionized by the collision with high-energy electrons, and then produced argon ions are transported to the test liquid surface, exchanging the charge with water molecule as follows:

$$
\begin{aligned}
& \mathrm{e}_{\text {fast }}+\mathrm{Ar} \rightarrow 2 \mathrm{e}_{\text {slow }}+\mathrm{Ar}^{+} \\
& \mathrm{Ar}^{+}+\mathrm{H}_{2} \mathrm{O}_{\mathrm{aq}} \rightarrow \mathrm{Ar}+\mathrm{H}_{2} \mathrm{O}^{+}{ }_{\text {aq }}
\end{aligned}
$$


where the subscript aq denotes an aqueous species. Since $\mathrm{H}_{2} \mathrm{O}^{+}$aq is unstable in water, it is immediately dissociated into $\mathrm{H}^{+}$aq and $\mathrm{OH}_{\mathrm{aq}}$ as shown in (3), resulting in the decrease of $\mathrm{pH}$ value.

$$
\mathrm{H}_{2} \mathrm{O}^{+}{ }_{\text {aq }} \rightarrow \mathrm{H}^{+}{ }_{\text {aq }}+\mathrm{OH}_{\mathrm{aq}}
$$

At $10 \mathrm{~s}, \mathrm{H}^{+}$aq flowing downward penetrates to the earthed electrode, and then diffuses horizontally along the earthed electrode. At $30 \mathrm{~s}$, the colored area expands by a vortex flow in the liquid, and the color of the liquid is widely changed to yellow by consecutive $\mathrm{H}^{+}$aq generation. At $300 \mathrm{~s}$, most of the liquid color assumes yellow, while the liquid color in the vicinity of the earthed electrode assumes blue, indicating the $\mathrm{pH}$ value over 7.6. Considering the continuity of electric current, the current flows through the gas-liquid boundary and the liquid-electrode boundary simultaneously and equivalency; therefore, electron transfer may occur from the earthed electrode to the liquid, corresponding to positive ion transfer from the gas phase to the liquid phase as shown in (2). The electrolysis of water at the cathode, as shown in (4), can take place, and $\mathrm{OH}^{-}$aq can be generated.

$$
\mathrm{e}+\mathrm{H}_{2} \mathrm{O}_{\mathrm{aq}} \rightarrow \mathrm{OH}^{-} \text {aq }+1 / 2 \mathrm{H}_{2 \mathrm{aq}}
$$

When the negative pulsed discharge plasma is generated, the color of the test liquid below the discharge area turns blue, and the colored area propagates downward at $2 \mathrm{~s}$. This coloration indicates the increase of $\mathrm{pH}$ value, namely, the generation of $\mathrm{OH}_{\text {aq. }}^{-}$Electrons, produced in the discharge plasma and transported to the liquid surface, dissolve into the liquid to form hydrated electrons $\mathrm{e}_{\mathrm{aq}}$ as shown in (5) [18].

$$
\mathrm{e} \rightarrow \mathrm{e}_{\mathrm{aq}}
$$

Since the hydrated electrons have high reduction potential, the electrons induce the reduction reactions, as shown in (6) and (7), contributing to $\mathrm{pH}$ value increase [19], [20].

$$
\begin{aligned}
& \mathrm{e}_{\mathrm{aq}}+\mathrm{H}_{2} \mathrm{O}_{\mathrm{aq}} \rightarrow \mathrm{H}_{\mathrm{aq}}+\mathrm{OH}^{-}{ }_{\mathrm{aq}} \\
& \mathrm{e}_{\mathrm{aq}}+\mathrm{H}^{+}{ }_{\mathrm{aq}} \rightarrow \mathrm{H}_{\mathrm{aq}}
\end{aligned}
$$

After $10 \mathrm{~s}, \mathrm{OH}^{-}$aq behaves similarly to $\mathrm{H}^{+}$aq in the positive pulsed plasma exposure. Finally, most of the liquid color assumes blue, while the liquid color in the vicinity of the earthed electrode assumes yellow at $300 \mathrm{~s}$. As shown in the case of positive pulse discharge, the electrolysis of water can take place at the anode, as shown in (8), and $\mathrm{H}^{+}{ }_{\text {aq }}$ can be generated.

$$
1 / 2 \mathrm{H}_{2} \mathrm{O}_{\mathrm{aq}} \rightarrow \mathrm{e}+\mathrm{H}^{+}{ }_{\mathrm{aq}}+1 / 4 \mathrm{O}_{2 \mathrm{aq}}
$$

Figure 5 shows the color change of the test liquid with BTB after $300 \mathrm{~s}$ of plasma exposure before and after stirring. The colors of the test liquid return to greenish blue after stirring, namely, the liquid become neutrality; therefore, the amounts of $\mathrm{H}^{+}{ }_{\text {aq }}$ and $\mathrm{OH}^{-}$aq generated in the test liquid are found to be equal in both the polarities. It is found that the equal amounts of $\mathrm{H}^{+}{ }_{\mathrm{aq}}$ and $\mathrm{OH}^{-}$aq, as shown in the reactions (2)-(4) and (5)-(8) by positive and negative pulsed discharge, respectively, are generated to satisfy the continuity of electric current through the gas-liquid and liquid-electrode boundaries.

\section{VISUALIZATION AND GENERATION OF $\mathrm{H}_{2} \mathrm{O}_{2}$}

Figure 6 shows the color change of the test liquid containing titanium sulfate by the pulsed discharge plasma exposure.
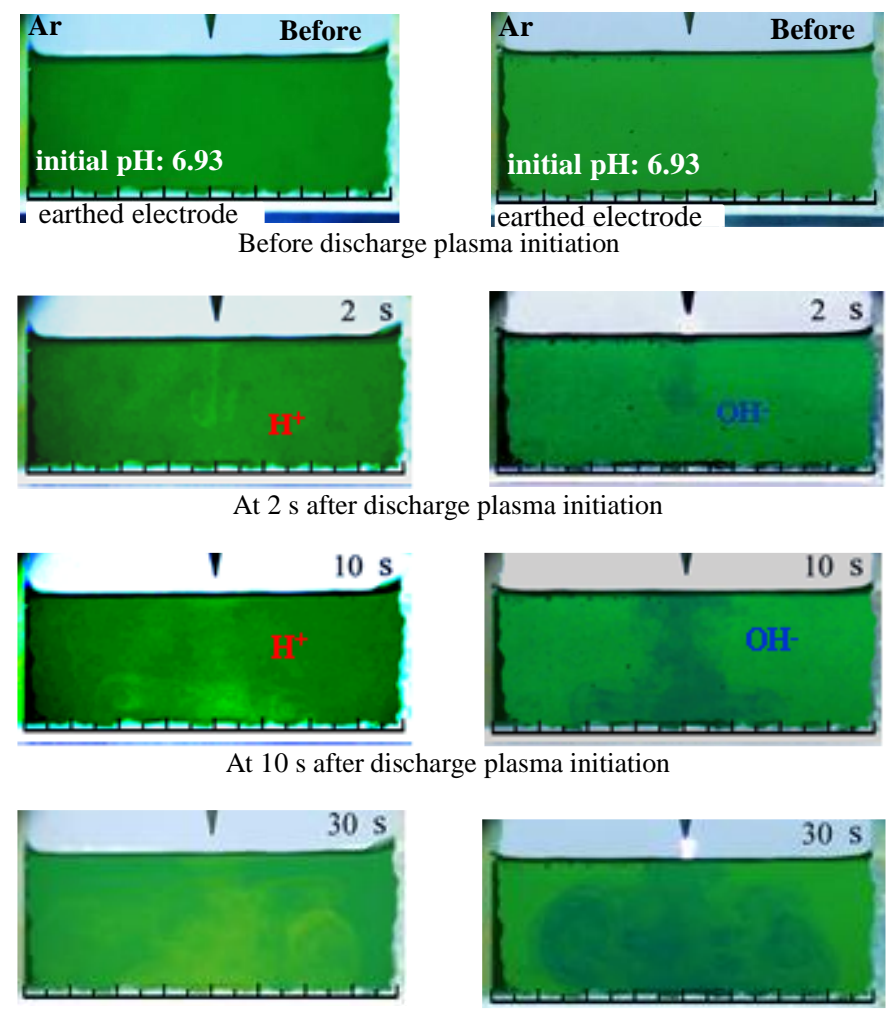

At $30 \mathrm{~s}$ after discharge plasma initiation
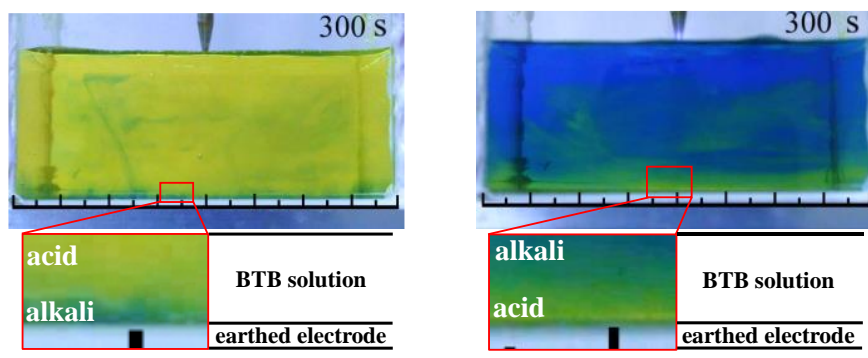

At $300 \mathrm{~s}$ after the discharge plasma initiation

(a) Positive polarity

(b) Negative polarity

Fig. 4. Color change of test liquid containing BTB by pulsed discharge plasma exposure.
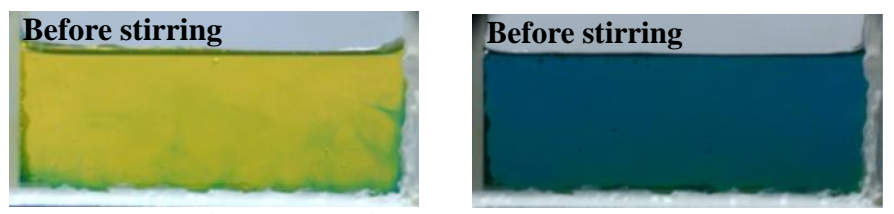

Before stirring (after 300 s plasma exposure)
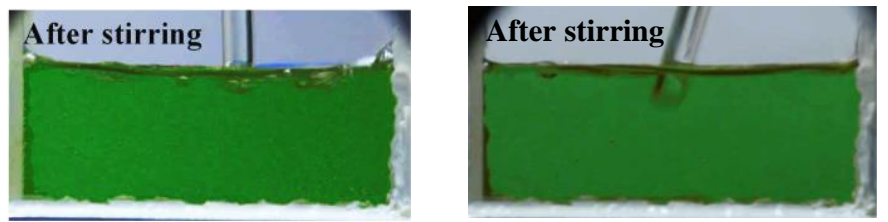

(a) Positive polarity

(b) Negative polarity

Fig. 5. Color change of test liquid with BTB after $300 \mathrm{~s}$ of plasma exposure before and after stirring. 
When the pulsed discharge plasma is generated, the color near the liquid surface turns slightly yellow at $30 \mathrm{~s}$, and the color and its area tend to be thicker and wider at $120 \mathrm{~s}$. Therefore, $\mathrm{H}_{2} \mathrm{O}_{2 \text { aq }}$ is found to be generated in the liquid surface. The colored area spreads horizontally near the liquid surface by consecutive $\mathrm{H}_{2} \mathrm{O}_{2}$ generation with the exposure time, but the color just under the needle electrode, where the discharge plasma develops, seems to be light. This is probably due to the decomposition of peroxotitanium complex by the pulsed discharge plasma. When the negative pulsed discharge plasmas is generated, the color is lighter than that in the positive pulsed discharge plasma exposure. Therefore, the $\mathrm{H}_{2} \mathrm{O}_{2}$ generation is found to be promoted in the positive polarity. When water is exposed to plasma, vaporized water molecules can be dissociated by the collision with high-energy electrons and metastable excited $\mathrm{Ar}$ atoms $\left(\operatorname{Ar}\left({ }^{3} \mathrm{P}\right)\right)$ in the discharge plasma, as shown in (9) and (11) [21], [22]. $\mathrm{H}_{2} \mathrm{O}_{2}$ can be generated from $\mathrm{OH}$ by reaction (12), and dissolves into the liquid [23], [24].

$$
\begin{aligned}
& \mathrm{e}_{\text {fast }}+\mathrm{H}_{2} \mathrm{O} \rightarrow \mathrm{e}_{\text {slow }}+\mathrm{OH}+\mathrm{H} \\
& \mathrm{e}_{\text {fast }}+\mathrm{Ar} \rightarrow \mathrm{e}_{\text {slow }}+\mathrm{Ar}\left({ }^{3} \mathrm{P}\right) \\
& \mathrm{Ar}\left({ }^{3} \mathrm{P}\right)+\mathrm{H}_{2} \mathrm{O} \rightarrow \mathrm{Ar}+\mathrm{H}+\mathrm{OH} \\
& \mathrm{OH}+\mathrm{OH} \rightarrow \mathrm{H}_{2} \mathrm{O}_{2} \\
& \mathrm{H}_{2} \mathrm{O}_{2} \rightarrow \mathrm{H}_{2} \mathrm{O}_{2 \text { aq }}
\end{aligned}
$$

As mentioned above, the electrical characteristics of the discharge are almost the same between the positive and negative polarities, so that the amounts of $\mathrm{H}_{2} \mathrm{O}_{2}$ generated in gas phase, as shown in (12), may be equivalent in both the polarities. In addition to the above $\mathrm{H}_{2} \mathrm{O}_{2}$ generation, $\mathrm{H}_{2} \mathrm{O}_{2 \text { aq }}$ may be generated from $\mathrm{OH}_{\mathrm{aq}}$, which is generated by the reaction (3) when the positive pulsed discharge plasma is generated. This results in the deeper color shown in color change at $120 \mathrm{~s}$ after the positive discharge plasma initiation in Fig. 6.

$$
\mathrm{OH}_{\mathrm{aq}}+\mathrm{OH}_{\mathrm{aq}} \rightarrow \mathrm{H}_{2} \mathrm{O}_{2 \mathrm{aq}}
$$

Figure 7 shows the $\mathrm{H}_{2} \mathrm{O}_{2}$ concentration in the test liquid as a function of plasma-exposure time. The $\mathrm{H}_{2} \mathrm{O}_{2}$ concentration increases in proportion to the exposure time, and the $\mathrm{H}_{2} \mathrm{O}_{2}$ concentration in the positive polarity is higher than that in the negative polarity. The difference of $\mathrm{H}_{2} \mathrm{O}_{2}$ generation rates between the positive and negative polarities is obtained to be $41.7 \mathrm{nmol} /(\mathrm{L} \cdot \mathrm{s})$. Assuming that $\mathrm{H}_{2} \mathrm{O}_{2 \text { aq }}$ is generated from $\mathrm{OH}_{\mathrm{aq}}$ through the reactions (1)-(3), the generation rate of $\mathrm{H}_{2} \mathrm{O}_{2 \text { aq }}$ can be obtained from the electrochemical calculation. The electric charge transfer from the gas phase to the liquid phase is obtained to be $1.53 \mathrm{mC} / \mathrm{s}$ from the time integration of the discharge current as shown in Fig. 3(a), so that the generation rate of $\mathrm{H}_{2} \mathrm{O}_{\mathrm{aq}}{ }^{+}$is calculated to be $15.9 \mathrm{nmol} / \mathrm{s}$ on the basis of Faraday's first law; therefore, the generation rate of $\mathrm{H}_{2} \mathrm{O}_{2 \text { aq }}$ is stoichiometrically obtained to be $7.95 \mathrm{nmol} / \mathrm{s}$. This rate is equivalent to $39.8 \mathrm{nmol} /(\mathrm{L} \cdot \mathrm{s})$ of $\mathrm{H}_{2} \mathrm{O}_{2 \text { aq }}$ generation rate in 200 $\mathrm{mL}$ of the test liquid. The calculated $\mathrm{H}_{2} \mathrm{O}_{2 \mathrm{aq}}$ generation rate is in approximate agreement with the measured $\mathrm{H}_{2} \mathrm{O}_{2}$ generation rate. This confirms the validity of the $\mathrm{H}_{2} \mathrm{O}_{2 \text { aq }}$ generation process from $\mathrm{OH}_{\mathrm{aq}}$, produced by the electrolysis of water, when the positive pulsed discharge plasma is generated.
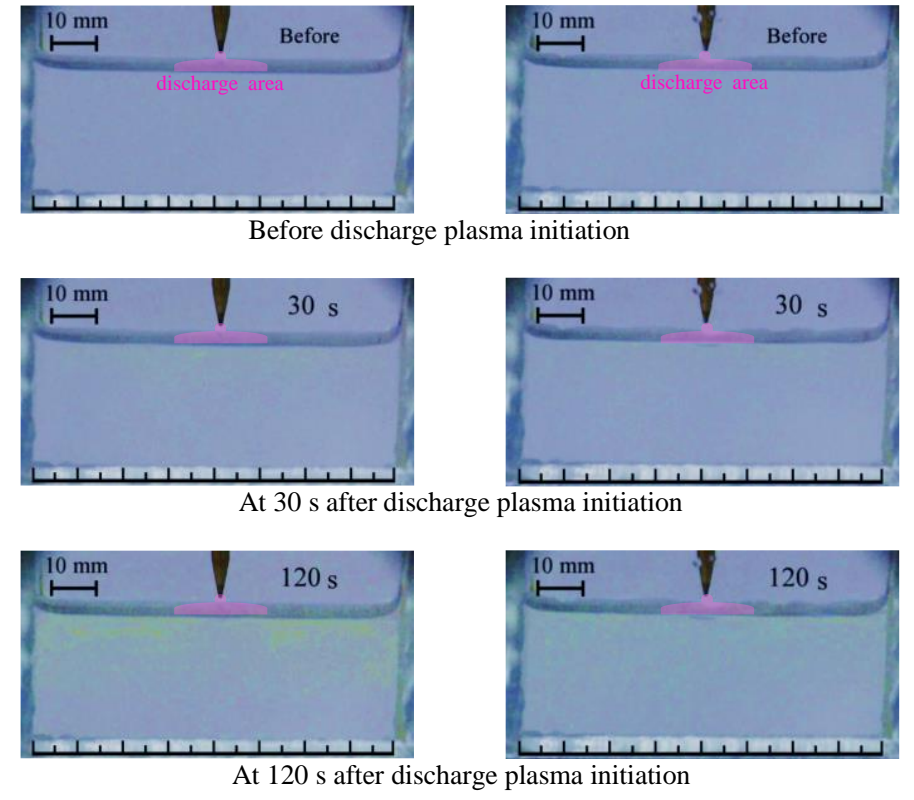

(a) Positive polarity

(b) Negative polarity

Fig. 6. Color change of test liquid containing titanium sulfate by pulsed discharge plasma exposure. (The figures is adjusted to $-20 \%$ brightness, $+20 \%$ contrast and $200 \%$ colorfulness.)

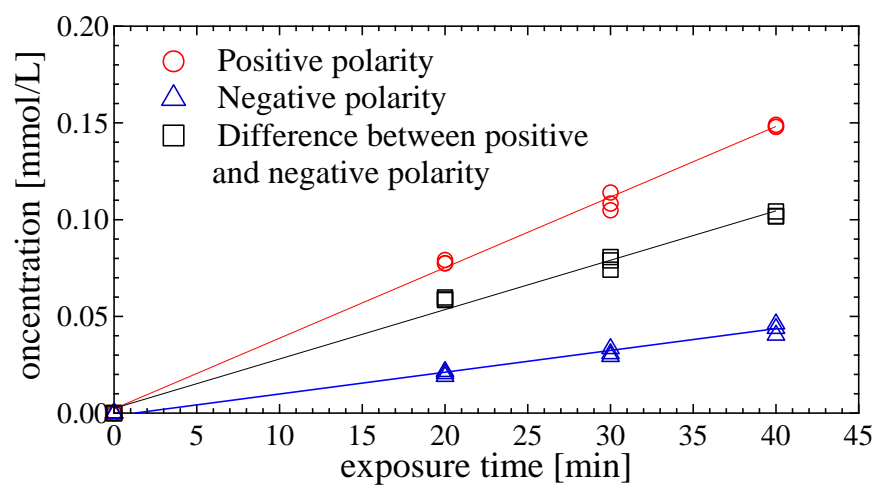

Fig. 7. $\mathrm{H}_{2} \mathrm{O}_{2}$ concentration in test liquid as a function of plasma-exposure time.

\section{CONCLUSION}

The variations of $\mathrm{pH}$ value and $\mathrm{H}_{2} \mathrm{O}_{2}$ concentration in the test liquid, exposed to pulsed discharge plasma with positive and negative polarities in Ar atmosphere, were visualized by a colorimetric method. It was found that the charge exchange reaction and the reaction of hydrated electron play important roles in the variation of $\mathrm{pH}$ value and $\mathrm{H}_{2} \mathrm{O}_{2 \text { aq }}$ generation. When the positive pulsed discharge plasma was generated, the $\mathrm{pH}$ value of the liquid began to decrease by $\mathrm{H}^{+}$aq generation through the charge exchange reaction. At the same time, $\mathrm{OH}^{-}$aq generation by the electrolysis of water at the cathode occurred, resulting in the increase of $\mathrm{pH}$ value in the vicinity of the earthed electrode. When the negative pulsed discharge plasma was generated, the $\mathrm{pH}$ value of the liquid began to increase by $\mathrm{OH}^{-}{ }_{\text {aq }}$ generation and $\mathrm{H}^{+}$aq reduction respectively through the reaction of hydrated electron with $\mathrm{H}_{2} \mathrm{O}_{\mathrm{aq}}$ and $\mathrm{H}^{+}$aq, while the $\mathrm{pH}$ value was simultaneously decreased in the vicinity of the earthed electrode by $\mathrm{H}_{\text {aq }}^{+}$generation through the electrolysis of water at the anode. Furthermore, $\mathrm{H}_{2} \mathrm{O}_{2}$ generation was found to be promoted when the positive pulsed discharge plasma was 
generated, and this increase rate was in approximate agreement with the calculated generation rate of $\mathrm{H}_{2} \mathrm{O}_{2 a}$, which is produced from $\mathrm{OH}_{\mathrm{aq}}$ generated by the electrolysis of water. This confirmed that the $\mathrm{pH}$ variation induced by the charge exchange reaction as well as the electrolysis of water takes place to satisfy electrical current continuity when the pulsed discharge plasma is generated.

\section{REFERENCE}

[1] D. P. Park et al., "Reactive nitrogen species produced in water by nonequilibrium plasma increase plant growth rate and nutritional yield," Current Applied Physics, Vol. 13, pp. 19-29, Jan. 2013.

[2] B.Sera, I. Gajdova, M. Sery and P.'Spatenka "New Physicochemical Treatment Method of Poppy Seeds for Agriculture and Food Industries," Plasma Science and Technology, Vol. 15, No.9, Sep. 2013.

[3] D. Z. Yang et al., "Atmospheric Pressure Gas-Liquid Diffuse Nanosecond Pulse Discharge Used for Sterilization in Sewage," Plasma process. Polym, Vol. 11, pp. 842-849, Sep. 2014.

[4] M. J. Traylor et al., "Long-term antibacterial efficacy of air plasmaactivated water," J. Phys. D: Appl. Phys., Vol. 44, no. 472001, pp. 4, Nov. 2016.

[5] N. K. Kaushik et al., "Cytotoxic macrophage-released tumour necrosis factor-alpha (TNF- $\alpha$ ) as a killing mechanism for cancer cell death after cold plasma activation," J. Phys. D: Appl. Phys., Vol. 49, no. 084001, pp.9, Jan. 2016.

[6] S. Mohades, M. Laroussi, J. Sears, N. Barekzi, and H. Razavi, "Evaluation of the effects of a plasma activated medium on cancer cells," Physics of plasma, Vol. 22, no. 122001, Oct. 2015.

[7] S. Jung, H. J. Kim, S. Park, H. I. Yong, J. H. Choe, H. J. Jeon, W. Choe and C. Job, "The use of atmospheric pressure plasma-treated water as a source of nitrite for emulsion-type sausage," Meat Science, Vol. 108, pp. 132 - 137, June. 2015

[8] S. Sato, K. Mori, O. Ariyada, A. Hyono and T. Yonezawa, "Synthesis of nanoparticles of silver and platinum by microwave-induced plasma in liquid," Surface \& coatlngs Tecnology, Vol. 206, pp. 955 - 958, Apr.2011.

[9] A. Kojtari et al., "Chemistry for Antimicrobial Properties of Water Treated With Non-Equilibrium Plasma," J. Nanomedine. Biotherapeutic. Discov., Vol. 4, no. 1000120, Dec.2013.

[10] M. Magureanu, C. Bradu, D. Piroi, N. B. Mandache and V. Parvulescu, "Pulsed Corona Discharge for Degradation of Methylene Blue in Water," Plasma Chem. Plasma process, Vol. 33, pp. 51 - 64, Nov. 2012.

[11] F. Huang, L. Chen, H. Wang, T. Feng and Z. Yan, "Degradation of methyl orange by atmospheric DBD plasma: Analysis of the degradation effects and degradation path," Plasma Chem. J. of electrostatics, Vol. 70, pp. 43- 47, Oct. 2011.

[12] J. Takahata et al., "Improvement of growth rate of plants by bubble discharge in water," Jpn. J. Appl. Phys., Vol. 54, no. 01 AG07, Dec. 2014.

[13] S. Ikawa, K. Kitano and S. Hamaguchi, "Effects of pH on Bacterial Inactivation in Aqueous Solutions due to Low-Temperature Atmospheric Pressure Plasma Application," Plasma. Process. Polym., Vol. 7, pp. 3342, Aug. 2009.

[14] P. Lukes, E. Dolezalova, I. Sisrova and M. Clupek, "Aqueous-phase chemistry and bactericidal effects from an air discharge plasma in contact with water: evidence for the formation of peroxynitrite through a pseudosecond-order post-discharge reaction of $\mathrm{H}_{2} \mathrm{O}_{2}$ and $\mathrm{HNO}_{2}$," Plasma Sources Sci. Technol., Vol. 23, No. 015019, Feb. 2014.

[15] T. Shimizu, Y. Iwafuchi, G. E. Morfill and T. Sato, "Formation of thermal flow fields and chemical transport in air and water by atmospheric plasma," New Journal of Physics, Vol. 13, No. 053025, May 2011.

[16] W. Tian and M. J. Kushner, "Atmospheric pressure dielectric barrier discharges interacting with liquid covered tissue," J. Phys. D: Appl. Phys., Vol. 47, no. 165201, April. 2014.

[17] G. M. Eisenberg, "Colorimetric Determination of Hydrogen Peroxide," Ind. Eng. Chem. Anal. Ed., Vol. 15, No. 5, pp. 327-328, Jan. 2009.

[18] P. Rumbach, D. M. Bartels, R. M. Sankaran and D. B. Go, "The effect of air on solvated electron chemistry at a plasma/liquid interface," $J$. Phys. D: Appl. Phys., Vol. 48, no. 424001, Sep. 2015.

[19] B. Valeur, J. Pouget, J. Bouson, M. Kaschke and N. P. Ernsting “Tuning of Photoinduced Energy Transfer in a Bichromophoric Coumarin Supermolecule by Cation Binding," J. Phys. Chem., Vol. 96, pp. 65456549, Apr. 1992.
[20] H. Shiraishi, G. R. Sunaryo and K. Ishigure, "Temperature Dependence of Equilibrium and Rate Constants of Reactions Inducing Conversion between Hydrated Electron and Atomic Hydrogen," J. Phys. Chem., Vol. 98, pp. 5164-5173, May. 1994.

[21] S. Kanazawa et al., "Observation of $\mathrm{OH}$ radicals produced by pulsed discharges on the surface of a liquid," Plasma Sources Sci. Technol., Vol. 20, No. 034010, Apr. 2011.

[22] T. Shiraguji et al., "Contribution of electrons, $\operatorname{Ar}\left({ }^{3} \mathrm{P}_{0,2}\right), \mathrm{H}_{2} \mathrm{O}^{+}$, and $\mathrm{H}_{3} \mathrm{O}^{+}$ to production of $\mathrm{OH}\left(\mathrm{A}^{2} \Sigma^{+}\right)$in a micron-dielectric barrier discharge $\mathrm{o}$ $\mathrm{Ar} / \mathrm{H}_{2} \mathrm{O}$," Jpn J. Appl. Phys., Vol. 54, 01AC03, Nov. 2015.

[23] J. N. Crowley et al., "Evaluated kinetic and photochemical data for atmospheric chemistry: Volume $\mathrm{V}$ - heterogeneous reactions on solid substrates," Atmos. Chem. Phys., Vol. 10, pp. 9059-9223, Sep. 2010.

[24] S. Mededovic, K. Takashima and A. Mizuno "Plasma Chemistry in pulsed Electrical Discharge in Liquid," Transaction of the Materials Research Society of Japan, Vol. 34, pp. 257-262, Dec. 2009.

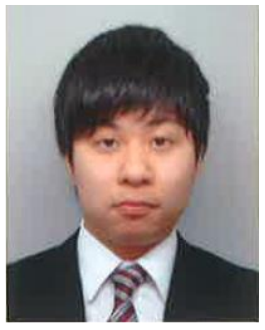

Shogo Wakisaka received the B. Eng. and M. Eng. degrees in Information and Electronic Engineering from Muroran Institute of Technology in 2016 and 2018.

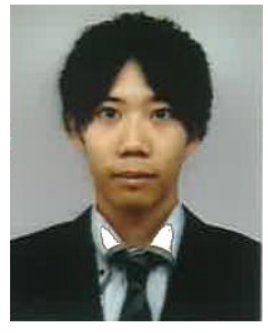

Kohshi Tsuda received the B. Eng. degree in Information and Electronic Engineering from Muroran Institute of Technology in 2018. He is currently a graduate student at Muroran Institute of Technology.

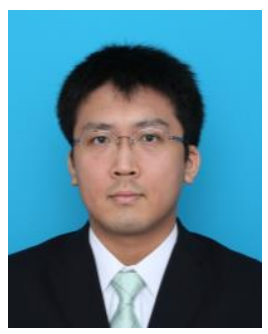

Kazuhiro Takahashi received the B. Eng. degree in Electrical and Electronic Engineering, the M. Eng. degree in Information and Electronic Engineering, and the Dr. Eng. degree in Production and Information Systems Engineering from Muroran Institute of Technology in 2009, 2011, and 2014, respectively. From 2014 to 2015, he was a Research Assistant with the Center of Environmental science and Disaster mitigation for Advanced Research, Muroran Institute of Technology. He has been an Assistant Professor at Muroran Institute of Technology. $\mathrm{He}$ is involved in the plasma desulfurization of production gas by underground coal gasification.

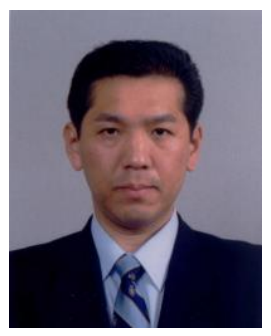

Kohki Satoh received the B. Eng. and M. Eng. degrees in Electrical Engineering from Muroran Institute of Technology in 1986 and 1988, respectively, and the Dr. Eng. degree in Electrical Engineering from Hokkaido University in 1991. He was a visiting researcher at Maquarie University Australia from 1995 to 1996 and at Strathclyde University UK in 2005 . He has been a Professor at Muroran Institute of Technology. He is involved in the plasma treatment of hazardous non-degradable substances. 